\title{
Corporate Social Responsibility, Profitability and Firm Value: Evidence from Indonesia
}

\author{
Zaky MACHMUDDAH ${ }^{1}$, Dian Wulan SARI $^{2}$, St. Dwiarso UTOMO ${ }^{3}$ \\ Received: June 17, 2020 Revised: July 05, 2020 Accepted: August 10, 2020
}

\begin{abstract}
The intention of this research is to identify the effect of corporate social responsibility (CSR) disclosure on firm value with profitability as a moderating variable. Data collection is carried out with data documentation that is based on financial reports and sustainability reports. All companies listed on the Indonesia Stock Exchange (IDX) during the 2013-2017 period are considered as the population of this study. Samples were selected using the purposive sampling method. The following are criteria that would be used in this study: 1) publish a sustainability report using the GRI G4 standard as a reference in preparing reports for 2013-2016, 2) publish a complete financial report for the 20142017 observation period, 3) not experience a loss during the 2014-2017 period. The total sample of the study was 109 companies. The study uses path analysis assisted with WarpPLS software version 6.0. The results show that the disclosure of corporate social responsibility has a positive and significant effect on firm value, and profitability moderates the effect of corporate social responsibility disclosure on firm value. The implication of the research is that implementing corporate social responsibility is very important to increase firm's value and firm's sustainability in the future.
\end{abstract}

Keywords: CSR Disclosure, Profitability, Firm Value

JEL Classification Code: G32, M14, M41

\section{Introduction}

The fluctuation of stock prices is a natural occurrence because it is driven by the power of supply and demand. Associated with the fluctuation of stock prices in the capital market is an interesting phenomenon related to the issue of the rise and fall of firm value itself. The following is one aspect

${ }^{1}$ First Author and Corresponding Author. Lecturer, Accounting Department, Faculty of Economic and Business, University of Dian Nuswantoro, Indonesia [Postal Address: JI. Nakula I No. 5-11, Semarang, Central Java, 50131, Indonesia]

Email: sekretariat@dinus.ac.id; zaky.machmuddah@dsn.dinus.ac.id ${ }^{2}$ Accounting Department, Faculty of Economic and Business, University of Dian Nuswantoro, Indonesia.

Email: 212201603174@mhs.dinus.ac.id

${ }^{3}$ Lecturer, Accounting Department, Faculty of Economic and Business, University of Dian Nuswantoro, Indonesia.

Email: dwiarso.utomo@dsn.dinus.ac.id

(c) Copyright: The Author(s)

This is an Open Access article distributed under the terms of the Creative Commons Attribution Non-Commercial License (https://creativecommons.org/licenses/by-nc/4.0/) which permits unrestricted non-commercial use, distribution, and reproduction in any medium, provided the original work is properly cited. of the fluctuation of share prices quoted from cnbcindonesia. com (2014): the performance of the composite stock price index (CSPI) has strengthened by $22.29 \%$. At the end of 2013, the Jakarta Composite Index (JCI) closed at 4,274.18 to $5,226.95$ at the end of 2014. More stable conditions will make JCI growth in the following year, 2015. The growth of the JCI this year is not only influenced by the domestic market, which is also inseparable from global factors that give negative sentiment which will affect Indonesia (www.liputan6.com). Throughout 2015, JCI fluctuated much, reaching a record high of 5,518.68 and also dropping at the level of 4033.59. JCI closing this year was down by $12.13 \%$ to $4,593.01$ compared to the end of 2014 at 5,226.95. The JCI, which declined this year, reflected a weakening Indonesian economy. This can be seen from the growth target this year, which only reached $4.7 \%$ down from $5.5 \%$. On the other hand, CSPI has also come under domestic and international pressure. As for pressures from within the country with absorption of the budget, low tax revenues, a weakening rupiah, and a slowing economy. Meanwhile, pressure from abroad was reflected in falling commodity prices, rising Fed interest rates, and a slowing world economy, especially China. 
JCI in 2016 closed at the level of 5,296. When viewed in year-to-date, JCI rose by $15.32 \%$ from the end of 2015 to 4,593 levels (www.cnnindonesia.co.id). Quoted by Liputan6. com (2016), the stable exchange rate of the rupiah against the US dollar was the driving force for the strengthening of the CSPI this year. Meanwhile, the improving condition of the Indonesian economy, namely, economic growth of around $5 \%$, is able to create less pressure. The closing of the Jakarta Composite Index in 2017, quoted by Bareksa. com (2017), successfully posted quite high growth, which increased by $19.99 \%$ to the level of 6355,654 , from 5296,711 at the end of the previous year. For IHSG, that number is the highest closing level. This year, the Jakarta Composite Index ranked 6th with the highest growth in the world if it is compared to several global exchanges in other countries. The sectors driving the JCI movement this year include the financial sector, which surged by $40.52 \%$, then the chemical industry, which rose by $28.06 \%$, and the consumer goods industry, which skyrocketed by $23.11 \%$. The sector managed to record the highest growth and was able to surpass the JCI performance (outperform) during 2017.

Based on the phenomenon above, the JCI movement is still very volatile every year. Some companies are rated well by investors and there are many companies whose movements are not too significant. This will be a separate consideration for investors before carrying out their investment activities or maybe for investors who have already invested, they will consider it again whether they will re-invest or not. Therefore, it can be interpreted that maintaining or increasing firm value is not easy and it is very important for the firm. The firm's value is defined as the investor's perception of the firm's level of success in managing resources, which is reflected in the firm's share price at the end of the current year. If the stock price is higher, the firm's value will also be higher, and vice versa, with the lower the stock price of a firm, the firm's value will also be lower so that the firm's performance will be considered unfavorable (Darmastika \& Ratnadi, 2019). To achieve the firm's goals in maximizing firm value, the firm needs to maintain good relations with the surrounding community by reducing the negative impact of the firm's operational activities in the form of firm contributions in the form of CSR disclosure. So, this has become a core element of strategic management and branding (Zahari et al., 2019; Lee, 2018; Kang \& Hwang, 2018).

The establishment of many companies results in increasingly uncontrolled utilization of natural resources, which then has a negative impact on the environment. From 2006, Lapindo became an example of a real case of environmental damage that has not yet ended the problem with the local community (www.cnnindonesia.com). With this case, the firm should further expand its social and environmental responsibilities. However, recent research states that the quality of corporate social responsibility
(CSR) revealed by companies in Indonesia is lower compared to companies from Thailand and Singapore (www. cnnindonesia.com). This is in line with the research findings of Yoon and Lee (2019) who underlie the importance of company characteristics in determining the influence of socially responsible activities. Interaction between the firm and the environment is necessary in order to produce a good corporate image in the community. When a firm is considered good by the community, the firm's business sustainability will surely be guaranteed. Conversely, if the negative impact caused by the firm's production activities is not immediately overcome, it can give a bad image of the firm, so that it will cause the firm's value to decline. On the other hand, the main goal of every firm is to maximize profits. If the firm's profits increase, firm value will also increase.

CSR disclosure can be interpreted as a form of corporate responsibility for the existence of social and environmental problems around the firm. Companies that disclose CSR optimally and sustainably are able to trigger an increase in firm value. Therefore, the application of CSR in the firm is very important. According to Putra and Wirakusuma (2015), the CSR is able to influence firm value. According to them, the firm will get many benefits when implementing CSR disclosure, while the intended benefit is that the firm will be increasingly in demand by investors. Besides, the firm's products will also be more liked by consumers. So, if the firm increases CSR disclosure, it will also increase firm value. This is in line with research, namely, Darmastika and Ratnadi (2019), Fasya (2019), Murnita and Putra (2018), Sunaryo et al. (2017), Sulistyaningsih et al. (2017), and Putra et al. (2017). However, on the contrary, Stiaji et al. (2016) and Ramona (2017) states that CSR has no influence on firm's value. According to them, it was caused by several factors, including differences in the reporting of CSR disclosures by each of the companies, in addition to investors inclined to judge the profitability of a firm compared to the firm's image in making investment decisions.

The influence between CSR and firm value will be stronger if the firm is in a profitable condition. Thus, profitability is considered capable of moderating the influence of CSR on firm value. This is in accordance with research by Darmastika and Ratnadi (2019), Fasya (2019), Murnita and Putra (2018), Sunaryo et al. (2017), Sulistyaningsih et al. (2017), and Ramona (2017). Their results suggest that profitability as a moderating variable is able to strengthen the relationship between CSR and corporate value. Companies that carry out CSR disclosures will increase the firm's reputation, so that firm's sales will also increase. As firm sales increase, so does firm profits. Companies that are in a profitable condition suggest that they have more funds that can be used to optimize CSR disclosure. Therefore, a high level of profitability can encourage a firm to carry out CSR disclosure activities in order to increase the level of 
Zaky MACHMUDDAH, Dian Wulan SARI, St. Dwiarso UTOMO /

firm sales. So, CSR will increase firm value if profitability within the firm also increases. However, this is not in line with research conducted by Putra et al. (2017) and Susanti et al. (2012). They say that the size of the profitability of a firm is not able to strengthen the influence of CSR on corporate value.

Findings of previous studies above still give inconsistent results. So, this is important to be explore the issue. The object of this study is all companies listed on the Indonesia Stock Exchange in the period 2013-2017 to examine the overall effect of CSR disclosure on firm value in all companies. Hence, the research does not assess the effect of CSR on firm value in certain sectors, but it includes all companies listed on the IDX.

\section{Literature Review}

\subsection{Stakeholder Theory}

Stakeholder theory assumes that the existence of a firm is determined by all firm stakeholders. This theory states that the firm is an entity that operates, not only for the interests of the firm itself, but also to provide benefits to all stakeholders. Therefore, the existence of a firm is strongly influenced by the support of stakeholders (Rosiana et al., 2013). Stakeholders are parties whose existence greatly influences, and are influenced, by companies such as employees, consumers, the community, government, and other parties. Susanti et al. (2012) states that the purpose of conducting a corporate social responsibility program is to balance the interests between the firm and its stakeholders. Stakeholders have the right to see various actions taken by a firm. If the wishes of the stakeholders are able to be fulfilled and accommodated well by the firm, it can produce a harmonious relationship between stakeholders and the firm. Therefore, CSR disclosure can be used as a strategy to maintain good relations with all firm stakeholders. A good relationship will generate profits for the firm if it is able to maximize the benefits that can be obtained from the establishment of a good relationship. One of the advantages to be gained by the firm is that the firm will achieve sustainability in running its business. In addition, the firm will gain an appreciation from stakeholders so that it will increase firm value. Therefore, to increase the firm value, the firm must pay attention to its stakeholders in every decision-making.

\subsection{Signaling Theory}

Murnita and Putra (2018) explain that signal theory discusses a firm that is required to be able to provide information to external parties so that it can affect firm value as reflected by changes in the firm's stock price because the market will respond to that information as a signal. In line with this statement, Rosiana et al. (2013) made it clear that signal theory can be interpreted as a corporate impulse to disclose information to external parties because information asymmetry occurs between management and external parties. That is caused by the firm knowing more about prospects to come than external parties. All firm information, both financial and non-financial, must be disclosed by the firm. Profitability is included in financial information that is considered important for investors in analyzing the increase in profits the firm gets from year to year. According to investors, a firm that is increasingly profitable means that it will give a positive signal that they will also benefit from their investment. In addition, other information that must be disclosed by the firm are CSR activities that are included in non-financial information that is disclosed in the firm's annual report. CSR disclosed by companies in their annual reports is considered very important by users of financial report to find out how good is the firm.

\subsection{Hypothesis Development}

By optimizing CSR disclosures, the firm will get a positive appreciation from the market, which is shown through an increase in the firm's stock price that in turn will increase the firm's value (Putra \& Wirakusuma, 2015). Putra et al. (2017) states that the implementation of CSR will benefit companies, namely, consumers will increasingly like the products of the firm, which will have an impact on the creation of a good image of the firm. Additionally, to the many consumers, increasing profits will later increase firm value. Firm value can increase with the CSR activities carried out by the firm. Thus, the increase in firm value will have an impact on encourage investors to invest in the firm. In making investment decisions, in addition to considering financial factors, investors also tend to pay attention to companies that have good business ethics and show social responsibility with all stakeholders as a form of concern for environmental impacts due to firm activities.

The implementation of CSR disclosure will also be a signal given by the firm to all firm stakeholders about the added value shown by the firm to its concern on the negative impacts caused by the firm's operational activities. This is in line with the signal theory which states that companies are encouraged to disclose all information including CSR to give signals to external parties that the firm is better than its competitors. Thus, companies that disclose information, in this case CSR activities, can provide more value to the firm, which will have an impact on increasing firm value.

\section{H1: CSR influences firm value}

Profitability has an important meaning in an effort to maintain the survival of the firm. It happens because 
profitability shows whether the business has good prospects in the future. Profitability can measure a firm's ability to carry out operational activities by maximizing profits and minimizing the firm's burden. Hence, it can increase firm value and attract the attention of investors to invest in the firm (Sunaryo et al., 2017). The implementation of corporate social responsibility disclosures, in this case CSR, is closely related to corporate profitability. This is because a firm that optimizes its CSR disclosure can increase the firm's attractiveness to investors. If there are more investors, their funds will have an impact on increasing firm profitability. Similarly, if the level of profitability of the firm is high, CSR disclosures carried out by the firm will be even greater. This means that the firm will set aside funds to disclose CSR activities more broadly. However, if the firm has a low level of profitability, the CSR disclosure the firm will carry out will also be lower, so that it will have an impact on the decline in firm value.

Firm value can increase as a result of increased sales by carrying out various social activities in the environment around the firm. Therefore, in this study, profitability is used as a moderating variable because theoretically the higher the level of profitability achieved by companies, the stronger will be the relationship of social disclosure (CSR) with firm value (Sulistyaningsih et al., 2017). If the profitability of a firm increases, the relationship between CSR and firm value will also be enhanced because the increasing profitability will have a positive impact on CSR disclosure carried out by the firm, which in turn, will have an impact on rising firm value (Putra et al., 2017). According to investors, companies that take responsibility for the environment are considered as companies that have good communication skills with stakeholders. This is related to stakeholder theory, which states that if the firm has a good relationship with stakeholders, then in the future the firm will not face problems with the community due to the firm's activities that will have an impact on decreasing the level of prosperity of shareholders and the firm's sustainability is threatened. Thus, companies must pay attention to stakeholders in every management decision-making because stakeholders greatly affect the existence of a firm. A high level of firm profitability and optimal CSR disclosed by the firm will encourage the firm to give a positive signal to external parties to show that the firm has more value than other companies. The research conducted by Wulandari et al. (2016) shows that increasing consumer loyalty over a long period of time will improve the firm's sales. Hence, in the end, the firm's profitability level is expected to increase.

H2: Profitability has a moderating effect of CSR disclosure on firm value.

\section{Research Methods and Materials}

The population in this study was all companies listed on the Indonesia Stock Exchange (IDX) during period 2013-2017. Samples were selected using the purposive sampling method. The following were sample criteria that would be used in this study: 1) publish a sustainability report using the GRI G4 standard as a reference in preparing reports for 2013-2016, 2) publish a complete financial report for the 2014-2017 observation period, and 3) not experience a loss in the 2014-2017 period. The source of the data obtained from the Indonesia Stock Exchange (IDX) is www.idx.co.id.

Firm value in this study is the dependent variable where this variable will be measured using the Tobin's Q formula. If the firm has a high Tobin's $Q$ value, it can be interpreted that the firm's growth will be better because investors will make more sacrifices for companies that have a market value of assets that is greater than the book value (Rosiana et al., 2013). The calculation of Tobin's $Q$ uses financial statement data for 2014-2017. The following is the formula used by Darmastika and Ratnadi (2019) in their research to calculate Tobin's Q:

$$
\text { Tobin's } \mathrm{Q}=(\mathrm{MVE}+\mathrm{DEBT}) / \mathrm{TA}
$$

MVE : Number of shares outstanding x Closing price DEBT : Total amount of debt

TA : Total assets

Measurement of CSR disclosure is using CSRDI (Corporate Social Responsibility Disclosure Index) proxy based on GRI G4 (Global Reporting Initiative Generation 4) standard, which is divided into 91 disclosure indicators. Then, the assessment of indicators is done by giving a score of 1 (one) on each item of disclosure, so that if the firm does not disclose 1 (one) item then the firm will be given a score of 0 (zero), whereas if the firm makes disclosure of 1 (one) item only then the score that will be 1 (one).

In calculating CSRDI, CSR disclosures of companies that will be used are from 2013-2016. This means that CSR disclosures carried out by the firm in 2013 will affect firm value in the following year, namely, 2014, and so on. Companies that disclose CSR in 2014 will affect firm value in 2015. Hence, companies that disclose CSR in year $t$ will affect firm value in year $\mathrm{t}+1$. According to (Sulistyaningsih, 2017), the formula that can be used in calculating CSRDI is as follows:

$$
\mathrm{CSRD}=\mathrm{xj} / 91
$$

CSRDI: Corporate Social Responsibility Disclosure Index $\mathrm{Xj}$ : $\quad$ Number of items disclosed by the firm 
Profitability of a firm shows how the financial performance of the firm generates profits (Ramona, 2017). In this study, the level of profitability is calculated using the ratio proxied by Return-On-Assets (ROA). As one measure of profitability, ROA shows the firm's ability to generate revenue from managing assets owned in terms of generating profits. ROA is used to measure the firm's ability to generate net income based on a certain level of assets, ROA can also be interpreted as one of the ratios that illustrates the firm's ability to generate profits from each asset used (Ramona, 2017).

ROA growth can provide a positive signal to the market that the firm is able to guarantee the welfare of investors through high investment returns. In addition, ROA growth will also convince investors that the firm has good growth prospects. This will have an impact on the increasing number of investors who will be motivated to increase stock demand transactions, so that the firm's stock price will increase, which will also be followed by an increase in the firm's value. Measuring profitability by using ROA as a proxy will be calculated using financial statement data from 2014-2017. The calculation of ROA according to Ramona (2017) can use the following formula:

$$
\begin{aligned}
\mathrm{ROA}= & \text { Earning After Tax }(\text { EAT }) / \\
& \text { Total Assets }
\end{aligned}
$$

\author{
EAT $\quad:$ Net profit after tax \\ Total Assets : Total assets
}

Data analysis in this study was conducted using the Partial Least Square (PLS) method. The data processing was done using WarpPLS 6.0. The stages of analysis using PLS-SEM had to go through five processes where each stage would affect the next stage. The first stage was conceptualizing the model. The second was determining the method of algorithm analysis. The third was determining the re-sampling method. The fourth was drawing a path diagram. The fifth was evaluating the model, and the last was reporting the results of the PLS analysis (Ghozali, 2016).

\section{Results and Discussion}

The companies used as research objects are companies listed on the Indonesia Stock Exchange in the period 20132017. The samples totaled 109 companies; the method used is purposive sampling which is a method of sampling by determining certain criteria presented in Table 1:

Table 2 explains the fit model with the data shown at an APC value of 0.023 , which is significant at $5 \%$. The model also does not contain multicollinearity because the AVIF value is 1.027 and it is below 5 .

\begin{tabular}{|c|c|c|c|c|c|c|}
\hline Num. & Sampling Criteria & 2014 & 2015 & 2016 & 2017 & Total \\
\hline \multirow[t]{2}{*}{1} & Number of companies listed on the IDX & 510 & 525 & 541 & 570 & 2146 \\
\hline & $\begin{array}{l}\text { Companies that do not publish sustainability reports with } \\
\text { GRI standards G4 as a reference }\end{array}$ & $(486)$ & $(489)$ & $(502)$ & (537) & $(2014)$ \\
\hline \multirow[t]{2}{*}{3} & Companies that suffered losses in the $2014-2018$ period & $(5)$ & $(8)$ & $(5)$ & $(5)$ & $(23)$ \\
\hline & Number of firm samples & 19 & 28 & 34 & 28 & 109 \\
\hline
\end{tabular}

Table 1: Research Samples for the 2014-2017 Period

Source: www.idx.co.id (data processed, 2020)

Table 2: Model Fit and Quality Indices

\begin{tabular}{|l|l|c|c|}
\hline Criteria & \multicolumn{1}{|c|}{ Fit Criteria } & \multicolumn{1}{|c|}{$\begin{array}{c}\text { The output } \\
\text { Model }\end{array}$} & \multicolumn{1}{|c|}{ Information } \\
\hline Average Path Coefficient (APC) & P-value $\leq 0.05$ & 0.023 & Model Fit \\
\hline Average R-Squared (ARS) & P-value $\leq 0.05$ & .166 & Weak \\
\hline Average Adjusted RSquared (AARS) & P-value $\leq 0.05$ & .202 & Weak \\
\hline Average Block VIF (AVIF) & Acceptable if $\leq 5 ;$ Ideally $\leq 3,3$ & 1,027 & Model Fit \\
\hline Average Full Collinearity (AFVIF) & Acceptable if $\leq 5 ;$ Ideally $\leq 3,3$ & 1,968 & Model Fit \\
\hline Goodness Tenenhaus & Small $\geq 0,1 ;$ Medium $\geq 0.25$ Large Besar 0.36 & .203 & Weak \\
\hline Sympson's Paradox Ratio (SPR) & Acceptable if $\geq 0.7 ;$ Ideally $=1$ & 1 & Model Fit \\
\hline R-Squared Contribution Ratio (RSCR) & Acceptable if $\geq 0.9 ;$ Ideally $=1$ & 1 & Model Fit \\
\hline Statistical Suppression Ratio (SSR) & Acceptable if $\geq 0.7$ & 0.500 & Weak \\
\hline $\begin{array}{l}\text { Nonlinear Bivariate Causality Direction } \\
\text { Ratio (NLBCDR) }\end{array}$ & Acceptable if $\geq 0.7$ & \multicolumn{2}{|c|}{ Wit } \\
\hline
\end{tabular}


R-Squared measurements are carried out to measure the model's ability to explain the variance of independent variables. In Table 3, it can be seen that the R-Square value is 0.041 . This means that the factors that influence firm value can be explained by the variable CSR and profitability of $4.1 \%$. While, the rest is explained by other factors outside this model.

Hypothesis testing intends to assess the validity of the research assumptions. The results of correlation between constructs are measured by looking at the path coefficient and the level of significance, which will then be compared with the hypotheses in this study. The following is a illustration of a research model obtained after processing data using WarpPLS 6.0:

$$
\begin{array}{ll}
\text { CSR } & : \text { Corporate Social Responsibility } \\
\text { ROA } & : \text { Return On Assets (Profitability) } \\
\text { TobinsQ } & : \text { Firm value }
\end{array}
$$

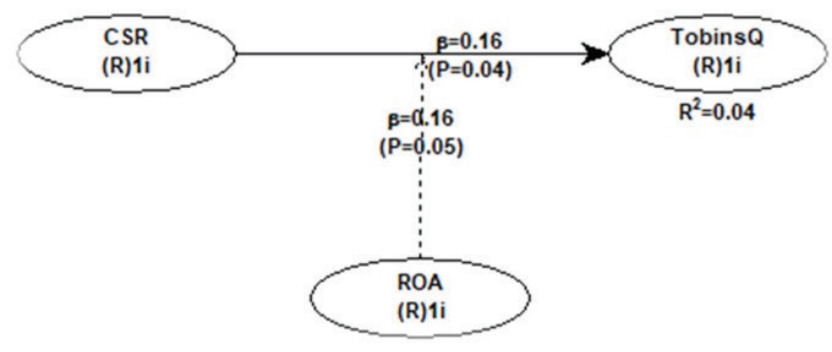

Figure 1: Research Result

Table 3: R-squared coefficients

\begin{tabular}{|l|c|c|c|}
\hline CSR & TobinsQ & ROA & CSR * ROA \\
\hline & 0.041 & & \\
\hline
\end{tabular}

Based on the illustration above, it can be interpreted that CSR has a significant influence on firm value, which is proxied by TobinsQ with a p-value of 0.04 . In addition, the positive beta coefficient value $\beta=0.16$ means that, if there is an increase in the evaluation of CSR by one unit, firm value will increase by 0.16 . The results of testing the effect of CSR variables on firm value by including the role of moderating variables, namely, profitability proxied by ROA, shows that the significance value of 0.05 has a positive direction. This can be seen from the results of the beta coefficient value $\beta=0.16$. So, it can be concluded that the ROA variable is able to strengthen the influence of CSR on firm value.

CSR disclosure in this study proved the affect of the firm value. The results of this study are consistent with signaling theory that companies that disclose CSR information can provide a positive signal to investors. For investors, companies that disclose CSR information in the annual report or in the sustainability report are considered to have more value because it means the firm takes responsibility for the negative impacts caused by operational activities carried out by the firm. Thus, if the firm discloses CSR activities optimally, it will trigger increased investment opportunities. As for the high investment opportunities, it can provide a positive signal to the firm's prospects in the future, which will increase firm value. Therefore, companies are required to disclose all information to external parties both financial and nonfinancial information with the aim of increasing firm value, which is reflected in changes in the firm's stock price because the market will respond to that information as a signal. The results of this study are in line with Darmastika and Ratnadi (2019), Fasya (2019), Murnita and Putra (2018), Sunaryo et al. (2017), Sulistyaningsih et al. (2017), Putra et al. (2017), Wulandari et al. (2016), Rosiana et al. (2013), Mandasari et al. (2013), and Susanti et al., (2012). However, they are contrary to the results by Stiaji et al. (2016) and Ramona (2017) who

\begin{tabular}{|c|c|c|c|c|c|}
\hline Criteria & Variable & CSR & TobinsQ & ROA & CSR * ROA \\
\hline \multirow[t]{4}{*}{ Path coefficient } & CSR & & & & \\
\hline & TobinsQ & .157 & & & .156 \\
\hline & $\mathrm{ROA}$ & & & & \\
\hline & $\mathrm{CSR}^{*} \mathrm{ROA}$ & & & & \\
\hline \multirow[t]{4}{*}{$P$ values } & CSR & & & & \\
\hline & TobinsQ & 0.045 & & & 0.046 \\
\hline & ROA & & & & \\
\hline & $\mathrm{CSR}^{*} \mathrm{ROA}$ & & & & \\
\hline \multirow[t]{4}{*}{ Effect size for path } & CSR & & & & \\
\hline & TobinsQ & 0.021 & & & 0.020 \\
\hline & ROA & & & & \\
\hline & $\mathrm{CSR} * \mathrm{ROA}$ & & & & \\
\hline
\end{tabular}
states that CSR does not have an influence on firm value.

Table 4: Path coefficients \& Effect Size 
Zaky MACHMUDDAH, Dian Wulan SARI, St. Dwiarso UTOMO /

Journal of Asian Finance, Economics and Business Vol 7 No 9 (2020) 631-638

The results showed that profitability was able to strengthen the influence of CSR on firm value. This is in line with stakeholder theory. If the wishes of the stakeholders are fulfilled by the firm, then it can produce a harmonious relationship between stakeholders and the firm. A harmonious relationship will make the firm achieve sustainability. Companies that disclose CSR activities can provide benefits to the firm, including, being able to show brand positioning, being able to increase the firm's reputation, and being able to increase market share and sales. When the firm's sales increase, it can be interpreted that the firm's profits also increase. Therefore, the higher level of profitability of the firm, the more extensive CSR disclosures is made by the firm. Hence, it can increase firm value because the firm is considered to set aside funds to make disclosures more broadly socially responsible. Hence, to increase firm value, the firm must pay attention to its stakeholders in every decision-making. The findings of this study are in line with Darmastika and Ratnadi (2019), Fasya (2019), Murnita and Putra (2018), Sunaryo et al. (2017), Sulistyaningsih et al. (2017), Ramona (2017), who state that profitability as a moderating variable is able to strengthen the relationship between CSR and firm value. However, this is not in line with research conducted by Putra et al. (2017) and Susanti et al. (2012) who state that the size of the profitability of a firm is not able to strengthen the influence of CSR on corporate value.

\section{Conclusions}

The findings of this study support the hypothesis development, namely, that CSR disclosure has an effect on firm value and profitability, which is able to moderate the effect of CSR disclosure on firm value. The limitation of this study is the low value of $\mathrm{R}$ square which is $4.1 \%$. Hence, the recommendation for future research is to create a new model by modifying or adding variables that are considered capable of increasing the value of $\mathrm{R}$ square, so that the results are better.

\section{References}

Darmastika, I. W. R., \& Ratnadi, N. M. D. (2019). The Effect of Corporate Social Responsibility Disclosure on Firm Value with Profitability and Leverage as Moderation Variables. E-Journal of Accounting, 27(1), 362-387. [Indonesian]

Fasya, A. (2019). The Influence of Corporate Social Responsibility Disclosure on Company Value with Profitability as a Moderating Variable. Journal of Information, Taxation, Accounting and Public Finance, 13(2), 145-162. [Indonesian]

Ghozali, I. (2016). Structural Equation Modelling (4th Ed.). Semarang, Indonesia: University of Diponegoro. [Indonesian]
Kang, E., \& Hwang, H. J. (2018). Strategic Management Plan for Transnational Organizations. Journal of Asian Finance, Economics and Business, 5(2), 119-128. https://doi. org/10.13106/jafeb.2018.vol5.no2.119

Lee, W. J. (2018). Group-affiliated Firms and Corporate Social Responsibility Activities. Journal of Asian Finance, Economics and Business, 5(4), 127-133. http://doi.org/10.13106/ jafeb.2018.vol5.no4.127

Mandasari, P. Y, Kamaliah, \& Hanif, R. A. (2013). The Influence of Corporate Social Responsibility to Firm Value with Profitability and Leverage as a Moderating Variable. Economic Journal, 21(4), 1-20. [Indonesian]

Murnita, P. E. M., \& Putra, I. M. P. D. (2018). The Effect of Corporate Social Responsibility on Company Value with Profitability and Leverage as Moderating Variables. E-Journal of Accounting, 23(2), 1470-1494. [Indonesian]

Putra, A. A., Kristanti, F. T., Yudowati, S. P. (2017). The Influence of Corporate Social Responsibility against Company Value with Profitability as a Moderating Variable. E Proceeding of Management. 53(9), 1689-1699. [Indonesian]

Putra, I. B. D., \& Wirakusuma, M. G. (2015). The Influence of Corporate Social Responsibility Disclosure on Company Value with Profitability as Moderating. E Journal of Accounting at Udayana University, 13(2), 461-475. [Indonesian]

Ramona, S. (2017). The Influence of Corporate Social Responsibility against Corporate Value with Profitability as a Moderating Variable. Journal of the Faculty of Economics in Accounting Study Program. Riau, Indonesia: Pasir Pengaraian University. [Indonesian]

Rosiana, G. A. M. E., Juliarsa, G., \& Sari, M. M. R. (2013). Pengaruh Pengungkapan CSR Terhadap Nilai Perusahaan Dengan Profitabilitas Sebagai Variabel Pemoderasi. E-Journal of Accounting at Udayana University, 5(3), 723-738. [Indonesian]

Stiaji, R. J., Diana, N., \& Afifudin. (2016). The Influence of Corporate Social Responsibility Against Company Value With Profitability as a Moderating Variable. E-Journal of Accounting, 53(9), 1689-1699. [Indonesian]

Sulistyaningsih, S., Wijayanti, A., \& Masitoh, E. (2017). The Influence of Corporate Social Responsibility against Company Value with Profitability as a Moderating Variable. IENACO National Seminar, 541-548. [Indonesian]

Sunaryo, I., Widarno, B., \& Suharno. (2017). The Influence of Corporate Social Responsibility Against Company Value With Profitability as a Moderating Variable. Journal of Accounting and Information Technology Systems, 27(9), 801-804. [Indonesian]

Susanti, F., Marietza, F., \& Indriani, R. (2012). The Influences of Corporate Social Responsibility to Firm Value with Profitability and Leverage as Moderating Variable. Proceeding The 13th Malaysia Indonesia Conference on Economics, Management and Accounting (MIICEMA) 2012. Available at: https://core.ac.uk/download/pdf/35334443.pdf [Indonesian] 
Wulandari, A. A., Ramantha, I. W., \& Wirakusuma, M. G. (2016). The Impact of Modified Profitability on the Effect of Corporate Social Responsibility on Manufacturing Company Value. E-Journal of Economic and Business at Udayana University, 5(7), 1889-1918. [Indonesian]

Yoon, B., \& Lee, J. H. (2019). Corporate Social Responsibility and Information Asymmetry in the Korean Market: Implications of Chaebol Affiliates. Journal of Asian Finance, Economics and
Business. 6(1), 21-31. http://doi.org/10.13106/jafeb.2019.vol6. no1.21

Zahari, A. R., Esa, E., Rajadurai, J., Azizan, N. A., \& Muhamad Tamyez, P. F. (2019). The Effect of Corporate Social Responsibility Practices on Brand Equity: An Examination of Malaysia's Top 100 Brands. Journal of Asian Finance, Economics and Business, 7(2), 271-280. https://doi. org/10.13106/jafeb.2020.vol7.no2.271 